\title{
Spinal motoneuron synaptic plasticity after axotomy in the absence of inducible nitric oxide synthase
}

\author{
Amanda Emirandetti, Gustavo F Simões, Renata G Zanon and Alexandre LR Oliveira*
}

\begin{abstract}
Background: Astrocytes play a major role in preserving and restoring structural and physiological integrity following injury to the nervous system. After peripheral axotomy, reactive gliosis propagates within adjacent spinal segments, influenced by the local synthesis of nitric oxide (NO). The present work investigated the importance of inducible nitric oxide synthase (iNOS) activity in acute and late glial responses after injury and in major histocompatibility complex class I (MHC I) expression and synaptic plasticity of inputs to lesioned alpha motoneurons.
\end{abstract}

Methods: In vivo analyses were carried out using C57BL/6J-iNOS knockout (iNOS-1-) and C57BL/6J mice. Glial response after axotomy, glial $\mathrm{MHCl}$ expression, and the effects of axotomy on synaptic contacts were measured using immunohistochemistry and transmission electron microscopy. For this purpose, 2-month-old animals were sacrificed and fixed one or two weeks after unilateral sciatic nerve transection, and spinal cord sections were incubated with antibodies against classical MHC I, GFAP (glial fibrillary acidic protein - an astroglial marker), Iba-1 (an ionized calcium binding adaptor protein and a microglial marker) or synaptophysin (a presynaptic terminal marker). Western blotting analysis of $\mathrm{MHCl}$ and $\mathrm{nNOS}$ expression one week after lesion were also performed. The data were analyzed using a two-tailed Student's $t$ test for parametric data or a two-tailed Mann-Whitney $U$ test for nonparametric data.

Results: A statistical difference was shown with respect to astrogliosis between strains at the different time points studied. Also, $\mathrm{MHCl}$ expression by iNOS-1- microglial cells did not increase at one or two weeks after unilateral axotomy. There was a difference in synaptophysin expression reflecting synaptic elimination, in which $\mathrm{iNOS}^{-1}$ mice displayed a decreased number of the inputs to alpha motoneurons, in comparison to that of C57BL/6J.

Conclusion: The findings herein indicate that iNOS isoform activity influences $\mathrm{MHC}$ I expression by microglial cells one and two weeks after axotomy. This finding was associated with differences in astrogliosis, number of presynaptic terminals and synaptic covering of alpha motoneurons after lesioning in the mutant mice.

\section{Background}

Nitric oxide (NO) is a gaseous free radical generated in most cells as a result of a diverse range of stimuli. This molecule may show protective effects in the nervous system, although pathologically elevated levels result in cytotoxicity. There are three major forms of enzyme that synthesize NO from L-arginine: the so-called NOS (nitric oxide synthases), with a 50-60\% sequence homology between species [1]; neuronal (nNOS or NOS I) and endothelial (eNOS or NOS III) types, comprising the

* Correspondence: alroliv@unicamp.br

1 Department of Anatomy, Institute of Biology, University of Campinas (UNICAMP), CP 6109, CEP 13083-970, Campinas, SP, Brazil

Full list of author information is available at the end of the article constitutive isoforms; and finally the inducible type (iNOS or NOS II). A fourth subtype of NOS (mtNOS) is an isoform of nNOS, and has been found in the inner mitochondrial membrane of several tissues including those of the liver, brain, heart and muscles [2,3].

The NO molecule has been implicated in several processes such as brain regulation $[4,5]$, liver microcirculation [6], neuronal regeneration [7-9], neuronal damage [10], elimination of misdirected axons [11] and synaptic plasticity [12]. However, in recent years researchers have noted a dual role for NO, acting either as a pro-apoptotic mediator [13] or as an anti-apoptotic agent [14,15]. NO can have a protective effect on dorsal root ganglion 
(DRG) neurons in vitro via inhibition of Bax and caspases [16]. On the other hand, systemic NO inhibition by $N \omega-$ nitro-L-arginine (NOLA) or $N$-nitro-L-arginine methyl ester (L-NAME) results in delayed axonal degeneration after intraorbital optic nerve transection [17].

Peripheral nerve lesions, such as sciatic nerve transection, induce upregulation of all NOS isoforms, as demonstrated by NADPH-diaphorase histochemistry [18], NOS immunohistochemistry $[19,20]$ and in situ hybridization [21]. Such increases in NOS expression result in enhanced expression of $\mathrm{NO}$ in the nerve microenvironment. Nevertheless, retrograde changes in response to peripheral axotomy also affect motoneuron cell bodies present in the spinal cord microenvironment. Secondarily to this, a prominent glial reaction develops in the spinal segments affected by a peripheral lesion, contributing to an intense rearrangement of synapses.

The mechanisms underlying neuron/neuron and neuron/glial communication after such lesioning remain poorly understood. Recently, the expression of the class I major histocompatibility complex (MHC I) was related to synaptic plasticity and to astrogliosis after peripheral nerve transection [22-26]. Interestingly, A/J mice, which present a greater axonal regeneration potential $[27,28]$, also display more robust glial fibrillary acidic (GFAP) and ERM (ezrin-radixin-miosin) protein expression in spinal cord after axotomy, when compared to other strains of mice [24-26]. The $\mathrm{Ca}^{2+}$-calmodulin-independent isoform, iNOS, is expressed by astrocytes, macrophages and microglia following immunological or inflammatory stimulation [29-31]. This isoform has also been reported in other cells such as human hepatocytes [32] and rat vascular smooth muscle cells [33]. After axotomy, knockout mice lacking iNOS show slower Wallerian degeneration and fewer regenerating myelinated fibers [9]. Also, the absence of inducible nitric oxide at the site of the lesion can be related to subsequent neuropathic pain and decreased functional hind limb recovery. It has been suggested that astrocytes and microglia may be implicated in such an outcome [34,35].

Taking into account the profound acute changes in spinal cord circuits following a peripheral lesion, it is possible that NO may be involved in signaling pathways that induce MHC I upregulation by neurons and glia. Thus the present study investigated the process of synaptic plasticity after peripheral axotomy in the spinal cord of knockout mice lacking the inducible form of nitric oxide synthase (iNOS-/). Different techniques (immunohistochemistry, western blotting and transmission electron microscopy) were used to investigate classical MHC I expression as well as glial responses following peripheral nerve injury. It is proposed that iNOS expression influences the outcome of the synaptic plasticity process in spinal cord, which is correlated with reduced MHC I expression.

\section{Methods \\ Animals}

For the present study, 30 6- to 8-week-old iNOS-1- http:// jaxmice.jax.org/strain/002596.html and 30 C57BL/6J agematched wild type (WT) mice ( 25.0 g body weight) were used. The animals were obtained from the Multidisciplinary Center for Biological Investigation (CEMIB/ Unicamp) and were housed with a $12 \mathrm{~h}$ light/dark cycle and free access to food and water. The study was approved by the Institutional Committee for Ethics in Animal Experimentation (CEEA/IB/Unicamp, proc. 1172-1), and all the experiments were carried out according to the guidelines of the Brazilian College for Animal Experimentation (COBEA). The mice from both strains were subjected to unilateral sciatic nerve transection as described below. The unlesioned sides were used as controls.

\section{Surgical procedures and tissue preparation}

The mice were anesthetized with a mixture of Kensol (Xylazin, König, $10 \mathrm{mg} / \mathrm{Kg}$ ) and Vetaset (Cetamin, Fort Dodge, $50 \mathrm{mg} / \mathrm{Kg} ; 1: 1,0.12 \mathrm{ml} / 25$ g, i.p.), and subjected to left sciatic nerve transection at level of the obturator tendon. A 2-mm-long segment of the distal stump was removed to avoid regeneration. Muscle and skin planes were sutured, and the animals allowed to survive for 1 or 2 weeks. All mice were sacrificed using an overdose of anesthetic, subjected to transcardial perfusion with $0.1 \mathrm{M}$ PBS (phosphate buffered saline, $20 \mathrm{ml}, \mathrm{pH}$ 7.4) and fixed either in 10\% formaldehyde in PB (phosphate buffer) for immunohistochemistry or with Karnovsky fixative (2.5\% glutaraldehyde and $1.0 \%$ paraformaldehyde in $0.1 \mathrm{M}$ phosphate buffer $\mathrm{pH}$ 7.4) for electron microscopy. Spinal cord segments L4-L6 were dissected out and either frozen (for immunohistochemistry), embedded in resin (for electron microscopy) or processed for western blotting analysis (non-fixed tissue).

\section{Immunohistochemistry}

Lumbar spinal cords from animals sacrificed one or two weeks after axotomy were frozen at $-40^{\circ} \mathrm{C}$ for cryostat sectioning (12 $\mu \mathrm{m}$ thickness). In the primary incubation, the following antisera were used: goat anti-GFAP (1:500, Santa Cruz Biotechnology, USA), rabbit anti-Iba-1 (antibody against the ionized calcium binding adaptor protein, 1:1000, Wako, USA [36]), rat anti-classical MHC I (ER-Hr52, which recognizes $\mathrm{H} 2-\mathrm{K}^{\mathrm{b}}$ and $\mathrm{H} 2-\mathrm{D}^{\mathrm{b}}$, the two classical MHC I in C57BL6/J mice, 1:200, BMA Biomedicals, Switzerland), mouse anti-nNOS (1:200, BD Biosciences, USA), mouse anti-iNOS (1:200, Santa Cruz Biotechnology, USA), mouse anti-NeuN (antibody 
against neuronal nuclear antigen, 1:600, Chemicon, USA) or rabbit anti-synaptophysin (an antibody against a protein present in the membrane of synaptic vesicles 1:200, Dako, Denmark). The antibodies were diluted in a solution containing BSA and Triton $\mathrm{x}-100$ in $0.01 \mathrm{M}$ PBS and the slides were post-fixed in cold acetone for 30 seconds prior to the classical MHC I incubation; the sections were incubated overnight at $4^{\circ} \mathrm{C}$ in a moist chamber. After rinsing in $0.01 \mathrm{M}$ PBS, sections were incubated with $\mathrm{Cy} 3$, Cy2 or FICT-conjugated secondary antisera (1:250, Jackson ImmunoResearch) for $45 \mathrm{~min}$ in a moist chamber at room temperature. The slides were then rinsed in PBS, mounted in a glycerol/PBS (3:1) mixture and observed using an inverted fluorescence microscope (Eclipse TS100, Nikon) equipped with a high resolution camera (DXM 1200F, Nikon). For quantitative measurements, the lesioned segments were first identified by the presence of decreased synaptophysin immunolabeling in the motoneuron microenvironment, combined with an increased glial reaction. Three alternate sections (ipsiand contralateral sides of the spinal cord) from each animal ( $\mathrm{n}=10$ for each group) were then used to capture images from the ventral horn at a final magnification of $\mathrm{x} 200$, always maintaining all settings unchanged. Because of the reduced area occupied by alpha motoneurons in the dorsolateral region of the ventral horn and because several sections were used to perform immunohistochemistry, 10 mice per group were used. However, only 5 animals per group were allocated for the quantitative analysis. Quantification was performed around the axotomized motoneurons using the enhance contrast and density slicing feature of IMAGEJ software (version $1.33 \mathrm{u}$, National Institute of Health, USA). The integrated density of pixels (sum of the gray values of each pixel in a determined area) around each motoneuron identified in the lateral motor nucleus was measured in eight circular areas from each side, as shown in Figure 1R. This quantification method measures the intensity of fluorescence in a given image, and has been used in previous studies [2326]. A lesioned/unlesioned ratio for the integrated density of pixels was calculated for each section (axotomy groups) and then a mean value was calculated for each spinal cord. The data are represented as mean \pm standard deviation (SD).

\section{Western blotting}

For quantification of MHC class I and nNOS expressions, 3-mm portions of lumbar spinal cord (L4-L6 segments) were cut from the right (contralateral) and left (ipsilateral to the axotomy) sides. All specimens were sonicated in Rippa buffer protein extraction medium $(150 \mathrm{mM} \mathrm{NaCl}$, $50 \mathrm{mM}$ Tris pH 8.0, $1 \mathrm{mM}$ PMSF, $1 \mathrm{mM}$ EDTA, $0.5 \% \mathrm{Na}-$ deoxycholate acid, $0.1 \%$ SDS and $1 \%$ Triton X-100) for 1 min. Total protein concentration was measured using Bio-Rad Bradford's protein assay.

Western blotting was performed after submitting 100 $\mu \mathrm{g}$ (MHC class I) or $40 \mu \mathrm{g}$ (nNOS) of protein extract from each tissue sample to electrophoresis in 10\% (MHC I) or $12.5 \%$ (nNOS) polyacrylamide gels under reducing conditions, and electric transfer to nitrocellulose membranes (Hybond-ECL; Amersham Biosciences, Chalfont St. Giles, United Kingdom). The membranes were blocked for $1 \mathrm{~h}$ with $1 \%$ or $5 \%$ nonfat milk powder in Tris buffered saline plus $0.2 \%$ Tween 20 (TBS-T) at room temperature, with agitation. Rat anti-MHC class I (ER-Hr52 monoclonal, 1:500, Peninsula, USA), mouse anti-nNOS (monoclonal, 1:500, Santa Cruz Biotechnology, USA) or rabbit anti-beta actin (polyclonal, 1:5000, Abcam, USA) antibodies were diluted in 0.1 or $1 \%$ nonfat milk powder in TBS-T and incubated overnight at $4^{\circ} \mathrm{C}$. After the primary antisera, three TBS-T washes were carried out and either HRP-conjugated rabbit anti-rat, rabbit anti-mouse or goat anti-rabbit IgG antibody (1:2500, in TBS-T, Zymed Laboratories, USA) - according to the host of the primary antibody - was added for $1 \mathrm{~h}$ at room temperature, with agitation. After a further set of washes, detection of the labeling was achieved by chemiluminescence (PerkinElmer, Waltham, USA). Band intensity was determined by densitometry using ImageJ Software (version $1.33 \mathrm{u}$, National Institute of Health, USA).

\section{Electron microscopy}

Lumbar spinal cords ( $\mathrm{n}=5$ for each group) were dissected out and stored overnight in fixative at $4^{\circ} \mathrm{C}$. The specimens were then trimmed, osmicated, dehydrated, and embedded in Durcupan (Fluka). Ultrathin sections from the L4-L6 segments were collected on formvarcoated copper grids, counterstained with $4 \%$ uranyl acetate and lead citrate, and examined under a transmission electron microscope operating at $60 \mathrm{KV}$ (Leo 906, ZEISS). Neurons with large cell bodies $(\sim 35 \mu \mathrm{m}$ in diameter), found in the sciatic motoneuron pool and cut in the nuclear plane, were identified as $\alpha$-motoneurons by the presence of C-type nerve terminals and chromatolysis (axotomized side). The cell surfaces were then sequentially digitalized at a magnification of $12.930 \mathrm{X}$ with a video camera connected to a computer, and the images mounted together using vectorial software. Synaptic terminals apposing the motoneuron somata were identified and their numbers per $100 \mu \mathrm{m}$ of cell membrane, as well as the membrane covering of all the terminals (calculated in percent of membrane length), determined using the measurement tool of Image Tool software (Version 3.0, The University of Texas Health Center, USA). The terminals were typed as F-type (with flattened synaptic vesicles), S-type (with spherical synaptic vesicles) or C-type (with a sub synaptic cistern), according to the procedure 


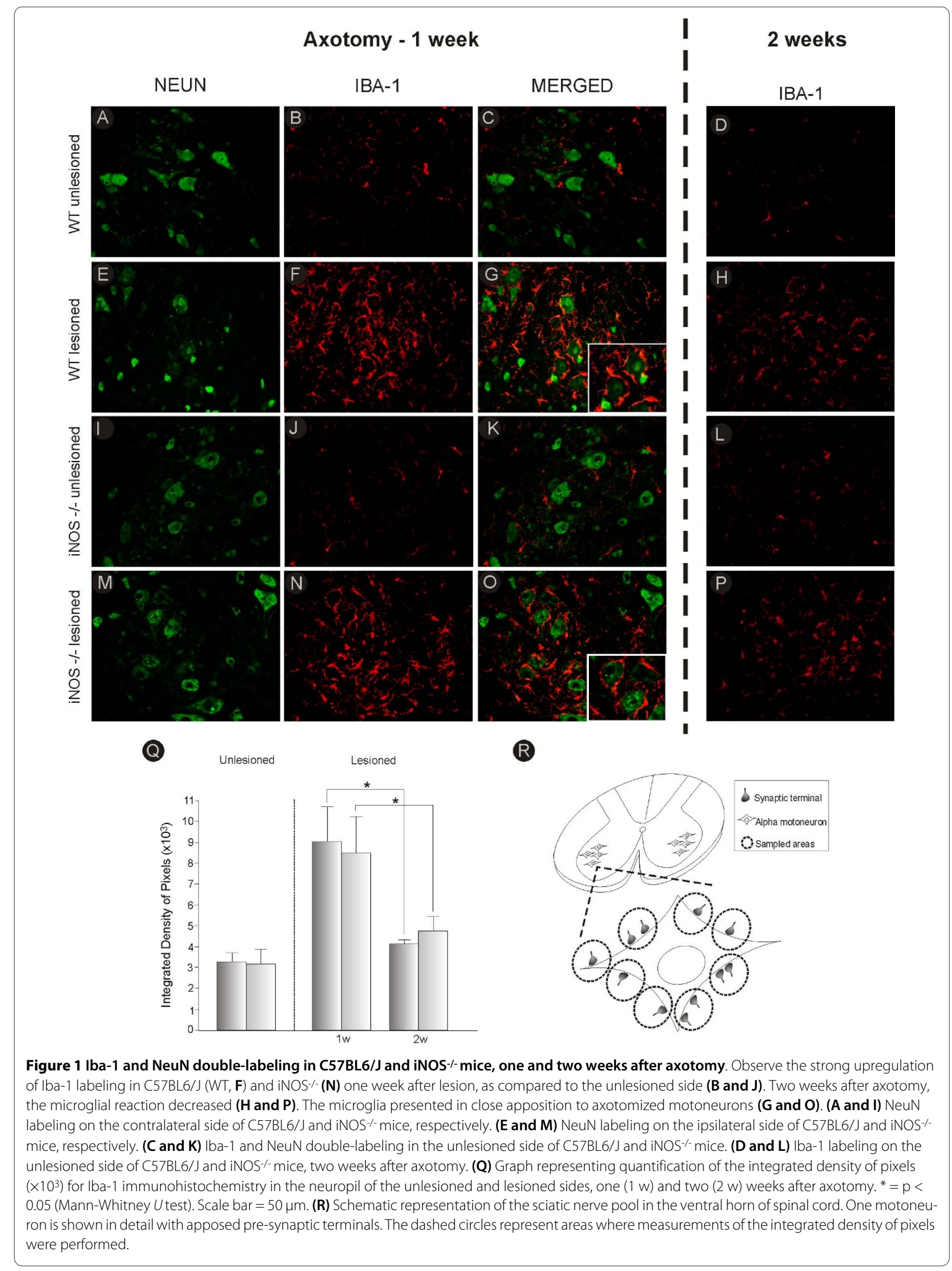


described by Conradi [37]. The distance between consecutive nerve terminals covering the motoneurons was also determined. A total of 30 sciatic $\alpha$-motoneurons (two neurons per animal in three groups of five animals: iNOSI- axotomized, WT axotomized and WT unlesioned) were quantified. The data were represented as the mean \pm standard deviation (SD).

\section{Statistical analysis}

The data were analyzed using a two-tailed Student's $t$ test for parametric data or a two-tailed Mann-Whitney $U$ test for nonparametric data at $\mathrm{p}<0.05\left(^{(*)}\right), \mathrm{p}<0.01{ }^{(* *)}$ ), and $\mathrm{p}$ $<0.001\left(^{* * * *}\right)$. The statistical analyses and graph plotting were done by using tools from a GraphPad Prism4 program.

\section{Results}

Glial reaction and classical MHC I spinal expression in the absence of inducible nitric oxide one and two weeks after lesioning

The effects of sciatic nerve transection on microglial reaction were assessed with quantitative measurements of immunoreactivity around the spinal cord motor nucleus one and two weeks after lesion, using anti-Iba-1 antiserum (antibody against the ionized calcium binding adaptor protein, a microglial marker [36]; Figure 1). Microglial cells were not reactive in the areas surrounding NeuN-labeled motoneurons on the unlesioned side (Figures. $1 \mathrm{C}$ and $1 \mathrm{~K}$ ) and quantitative analysis showed no statistical differences between $\mathrm{C} 57 \mathrm{BL6} / \mathrm{J}$ and iNOS- $/$ mice (C57BL6/J, $3.13 \times 10^{3} \pm 0.62$; iNOS $/ /, 3.20 \pm 0.47$; Figure $1 \mathrm{Q}$ ), indicating that both strains displayed equivalent basal expression of the referred protein (also seen in Figures $1 \mathrm{~B}$ and $1 \mathrm{~J}$ ). However, there was an increase in Iba1 expression on the lesioned side of both strains one and two weeks after axotomy (Figures $1 \mathrm{~F}, \mathrm{~N}, \mathrm{H}$ and $1 \mathrm{P}$ ). It is important to emphasize the close relationship between the axotomized $\alpha$-motoneurons and the reactive microglia, as depicted in figures $1 \mathrm{G}$ and $1 \mathrm{O}$, respectively. The integrated density of pixels in the lesioned side was also determined and showed statistical differences between the two studied time points in both strains (C57BL6/J one week, $8.43 \times 10^{3} \pm 0.47$; two weeks, $4.70 \times 10^{3} \pm 0.73$, p < 0.05 and iNOS -1 - one week, $8.99 \times 10^{3} \pm 1.48$; two weeks, $4.08 \times 10^{3} \pm 0.21, \mathrm{p}<0.05$, Figure $\left.1 \mathrm{Q}\right)$.

In order to analyze expression of classical MHC I in ventral horn, Iba-1 and MHC I double labeling was performed. Such immunolabeling also assured that the spinal segments analyzed contained lesioned $\alpha$ motoneurons (Figure 2). Lesioning did not result in any significant increase of MHC I expression on the unlesioned side (not shown). However, at both one and two weeks after axotomy the C57BL6/J mice showed significant upregulation of MHC I protein in the surroundings of the motoneurons on the lesioned side (Figures $2 \mathrm{~B}$ and 2D). This difference in MHC I expression by wild type microglial cells at different time points after lesioning is shown in Figure 2J (C57BL6/J one week, $6.51 \times 10^{3} \pm 0.49$; two weeks, $\left.9.06 \times 10^{3} \pm 1.43, \mathrm{p}<0.05\right)$. Interestingly, the elevated expression of MHC I in wild type mice co-localized with Iba-1 labeling (Figure 2C). Also, MHC I expression in iNOS knockout mice was not increased at either 7 or 21 days after axotomy (Figures $2 \mathrm{~F}$ and $2 \mathrm{H}$ ), indicating that the absence of MHC I expression in iNOS-/- mice does not represent a delayed response but rather a collateral effect of the gene knockout. Western blot analysis confirmed the data obtained one week after lesioning and is depicted in Figure 2I (C57BL6/J $3.81 \pm 2.05$; iNOS $/$ $2.19 \pm 0.81, \mathrm{p}<0.05$, contralateral; C57BL6/J $5.98 \pm 2.23$;

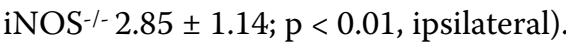

The level of astroglial reaction one and two weeks after axotomy was also studied in iNOS- - - and WT mice by measuring immunostaining in the neuropil adjacent to lesioned NeuN-labeled motoneurons (Figure 3). To determine whether astrocytes could express classical MHC I, double labeling was performed using antibodies against GFAP and MHC I (Figure 4). As shown in Figure 4C, no significant co-localization was obtained.

There was a statistically significant difference in basal expression of GFAP between the two strains (as shown in Figures $3 \mathrm{~B}$ and $3 \mathrm{~J}$ ). C57BL6/J mice displayed stronger basal labeling for GFAP compared to iNOS -1 mice (C57BL6/J, $2.169 \times 10^{3} \pm 0.11 ;$ iNOS $^{-1-}, 0.98 \times 10^{3} \pm 0.14$, p $<0.001$; Figure 5Q). However, there was upregulation of GFAP expression one week (C57BL6/J, $5.01 \times 10^{3} \pm 0.22$; iNOS - - $\left., 4.24 \times 10^{3} \pm 0.80, \mathrm{p}<0.05\right)$ and two weeks (C57BL6/J, $6.01 \times 10^{3} \pm 0.49$; iNOS ${ }^{-/}, 4.76 \times 10^{3} \pm 0.44$, p $<0.01$ ) after sciatic nerve transection (Figure 3Q). GFAP labeling was more robust in iNOS ${ }^{-/}$mice 14 days after nerve lesion, as compared to one week post axotomy ( $\mathrm{p}<$ 0.01 , Figure $3 \mathrm{Q}$ ). It is important to emphasize that the astroglial reaction presented a diffuse pattern in normal mice (Figure $3 \mathrm{~F}$ and $3 \mathrm{H}$ ), whereas it was restricted to the surroundings of the sciatic motoneuron pool in iNOS deficient mice (Figure $3 \mathrm{~N}$ and $3 \mathrm{P}$ ).

\section{Loss of inputs to axotomized iNOS--- spinal a-motoneurons} is shown by a decrease in synaptophysin labeling

To analyze changes in synaptic activity resulting from axotomy, quantitative measurements of the expression of the synaptic protein synaptophysin were made for the sciatic motor nuclei of iNOS $-1-$ and C57BL6/J mice. Only large motoneurons present in the dorsolateral nucleus, which supplies the distal hind limb muscles, were considered for analysis. Figures 5A and 5B show similar synaptophysin immunoreactivity in ventral horn of WT and iNOS-deficient mice (Figure 5C). In both cases, a clear 


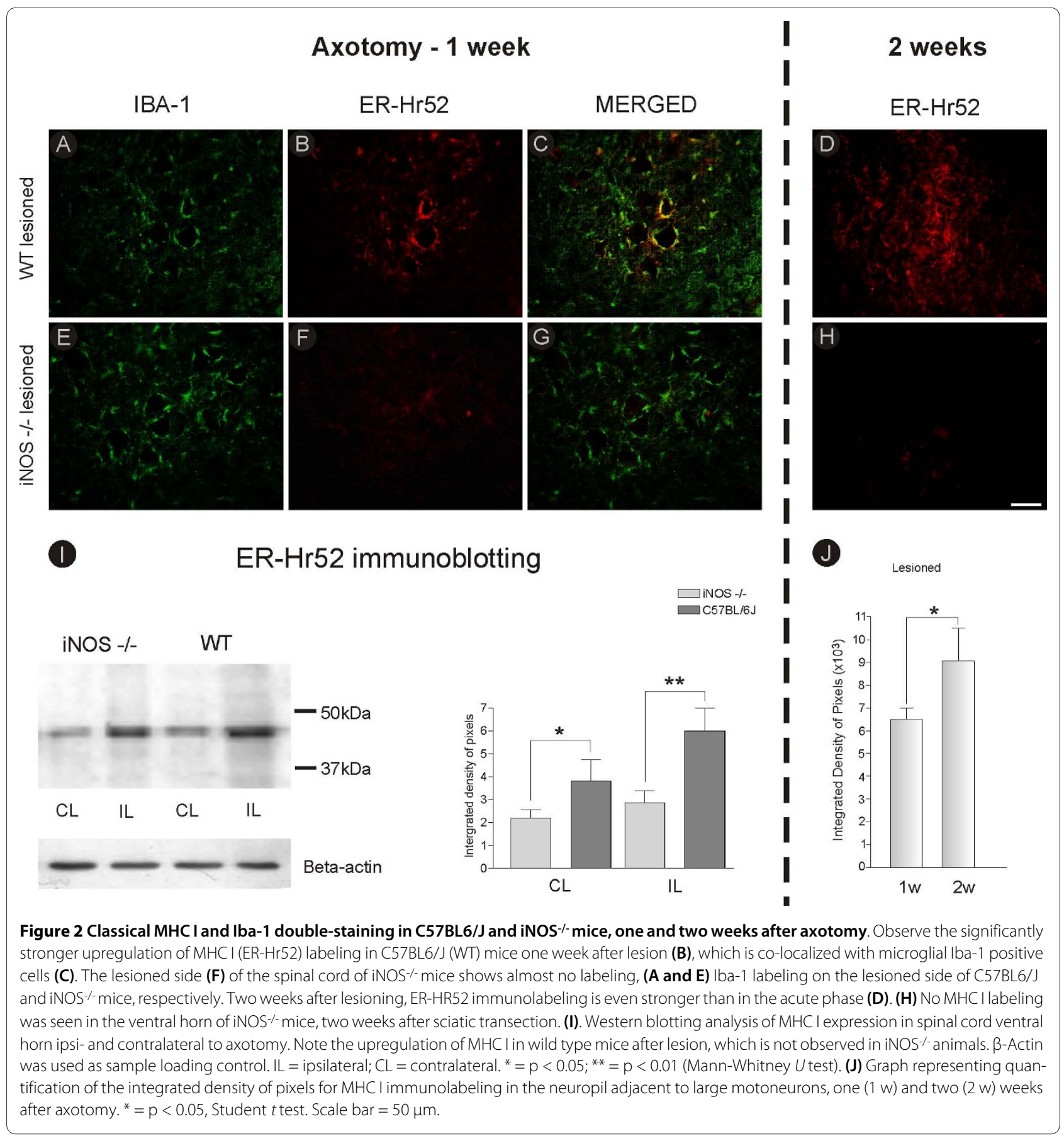

decrease in synaptophysin labeling occurred in the motor nuclei on the lesioned side, although this reduction was significantly greater in iNOS $/$ - as compared to C57BL6/J mice (C57BL6/J, $0.72 \pm 0.05$; iNOS $-1-, 0.53 \pm 0.03, \mathrm{p}<$ 0.05 , lesioned/unlesioned side ratio, Figure $5 \mathrm{E})$. The scheme shown in Figure 5F indicates the circular areas (100 $\mu^{2}{ }^{2}$ each) used for quantification of immunofluorescence. The differential degree of synaptic elimination observed by immunohistochemistry was further assessed using transmission electron microscopy, and these results are described below.

\section{Synaptic elimination, glial reaction and MHC expression are not influenced by neuronal nitric oxide synthase isoform (nNOS)}

An important question to answer was whether the glial and neuronal events in response to sciatic nerve transection could be related to differential neuronal expression of $\mathrm{nNOS}$ in C57BL6/J mice after axotomy. For this pur- 


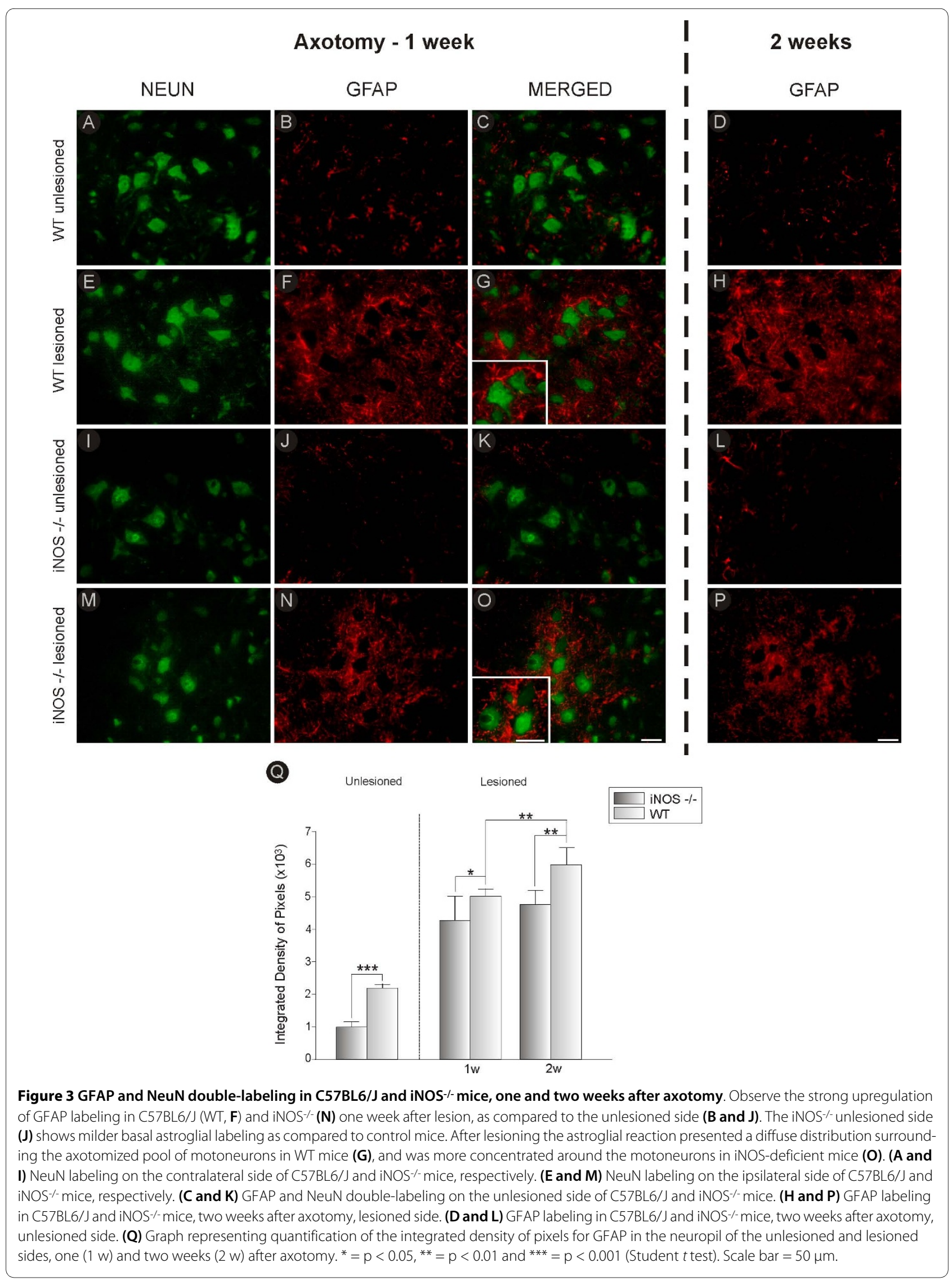




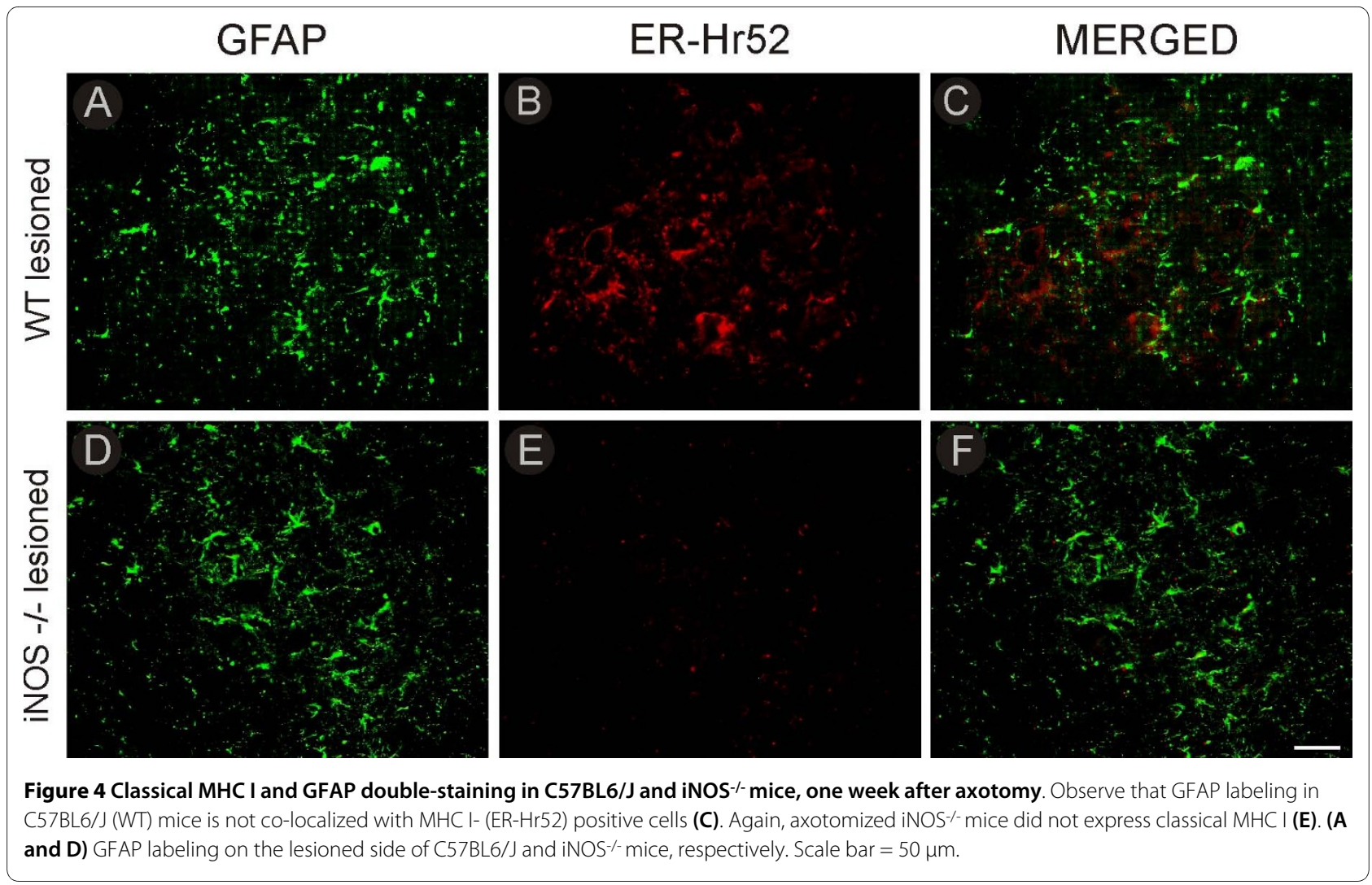

pose, immunohistochemistry using anti-nNOs antibody was performed in iNOS $^{-/-}$and C57BL6/J spinal cords (Figure 6). nNOS immunolabeling was observed within neurons throughout the spinal cord, including large motoneurons in both wild type and iNOS knockout mice (Figures 6C and 6D, respectively). Western blot analysis confirmed the immunolabeling results obtained in situ, and indicated that axotomy did not result in statistically significant nNOS activity upregulation (Figure 6E). Figure 6A shows iNOS expression by C57BL6/J glial cells one week $(1 \mathrm{w})$ after transection. Such up-regulation was not detectable on the lesioned side, two weeks ( $2 \mathrm{w})$ after axotomy.

\section{Faster synaptic elimination in iNOS-deficient mice after lesioning (Figures 7, 8 and 9)}

To better understand the different processes involved during synaptic elimination in iNOS-deficient and WT mice, a thorough ultrastructural analysis of inputs to $\alpha$ motoneurons in the sciatic nerve pool was carried out. The general ultrastructure appeared identical for both mice strains studied. The total synaptic covering, which represents the motoneuron body surface in contact with presynaptic terminals, revealed the same general density of synapses in unlesioned iNOS-/- and C57BL6/J mice, as shown in Figure 7A (C57BL6/J, 52.43\% $\pm 0.74 \%$; iNOS $^{-1-}$, $46.28 \% \pm 4.38 \%)$. However, one week after axotomy, the synaptic elimination process differed significantly when the strains were compared (C57BL6/J, 31.63\% $\pm 0.57 \%$; iNOS $/-, 24.61 \% \pm 1.69 \%, \mathrm{p}<0.01)$. Moreover, total counts of terminals apposed to the motoneuron surface revealed a smaller number of boutons per $100 \mu \mathrm{m}$ on the right side in the absence of iNOS (C57BL6/J, $36.08 \pm 3.87$; iNOS - $^{-}$, $26.89 \pm 0.93, \mathrm{p}<0.05$, Figure $8 \mathrm{C})$. These values were even lower after axotomy (C57BL6/J, $22.58 \pm 1.39$; iNOS $^{-1-}$, $13.43 \pm 1.27, \mathrm{p}<0.01$, Figure $8 \mathrm{C}$ ). The results described above were further investigated under TEM in order to determine whether there was any qualitative difference in type of preserved inputs in the two referred strains. As described earlier [37], there are two main categories of synaptic terminals on motoneurons, which can be typed according to the shape of their synaptic vesicles. Type $S$ terminals, with spherical vesicles, mostly contain the excitatory neurotransmitter glutamate, although a small proportion of large $\mathrm{S}$ terminals are cholinergic (C) $[38,39]$. When observed under TEM, the F terminals contain flattened or pleomorphic vesicles filled with glycine and/or GABA [40,41], and work as inhibitory inputs. Qualitative analysis of F, S and C boutons, presented in Figures 7 and 8, reveals that a greater number of $F$ terminals were preserved in apposition to sciatic motoneurons in C57BL6/J mice as compared to iNOS $/$ - mice (C57BL6/ J, $15.12 \pm 1.18$; iNOS ${ }^{-/}, 8.78 \pm 1.00, \mathrm{p}<0.01$, Figure 8D) one week after cutting the sciatic nerve. $\mathrm{S}$ terminals were 


\section{Synaptophysin}
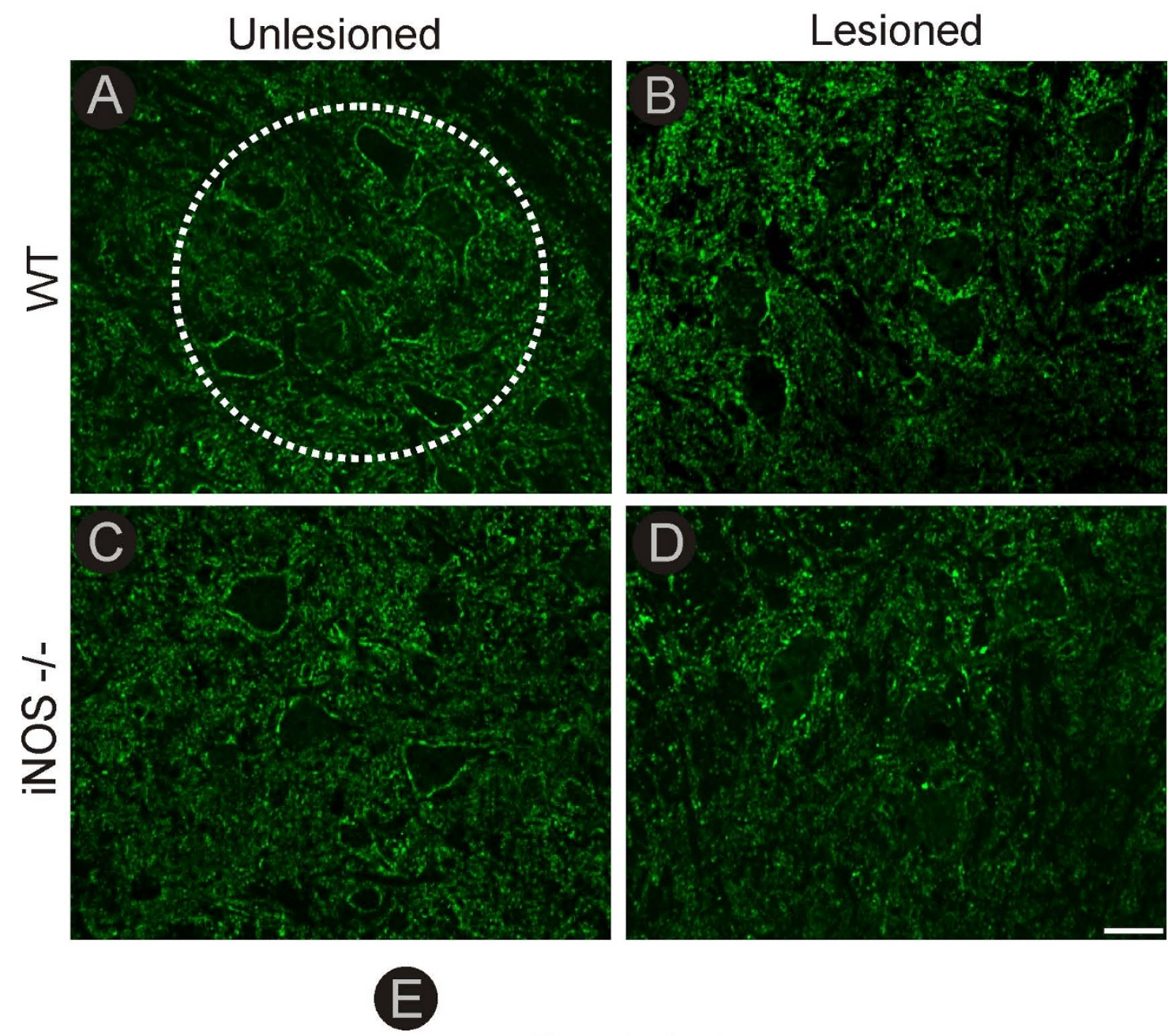

\section{Synaptophysin}

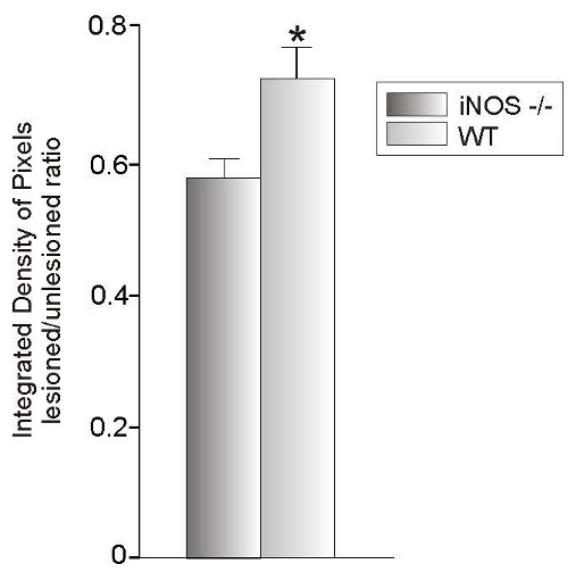

Figure 5 Synaptophysin immunostaining in C57BL6/J and iNOS--mice, one week after unilateral axotomy. Note that one week after lesioning, there was a stronger decrease in labeling especially in the areas surrounding the motoneurons. This decrease was more intense in iNOS $\%$ mice (D) than in C57BL6/J mice (B). (A and C) Unlesioned side of C57BL6/J and iNOS-1- mice, respectively. The dashed circle indicates the motor nucleus containing the alpha motoneurons. (E) Graph representing quantification of the integrated density of pixels in the neuropil adjacent to large motoneurons. ${ }^{*}=\mathrm{p}<0.05$ (Student $t$ test). Scale bar $=50 \mu \mathrm{m}$. 


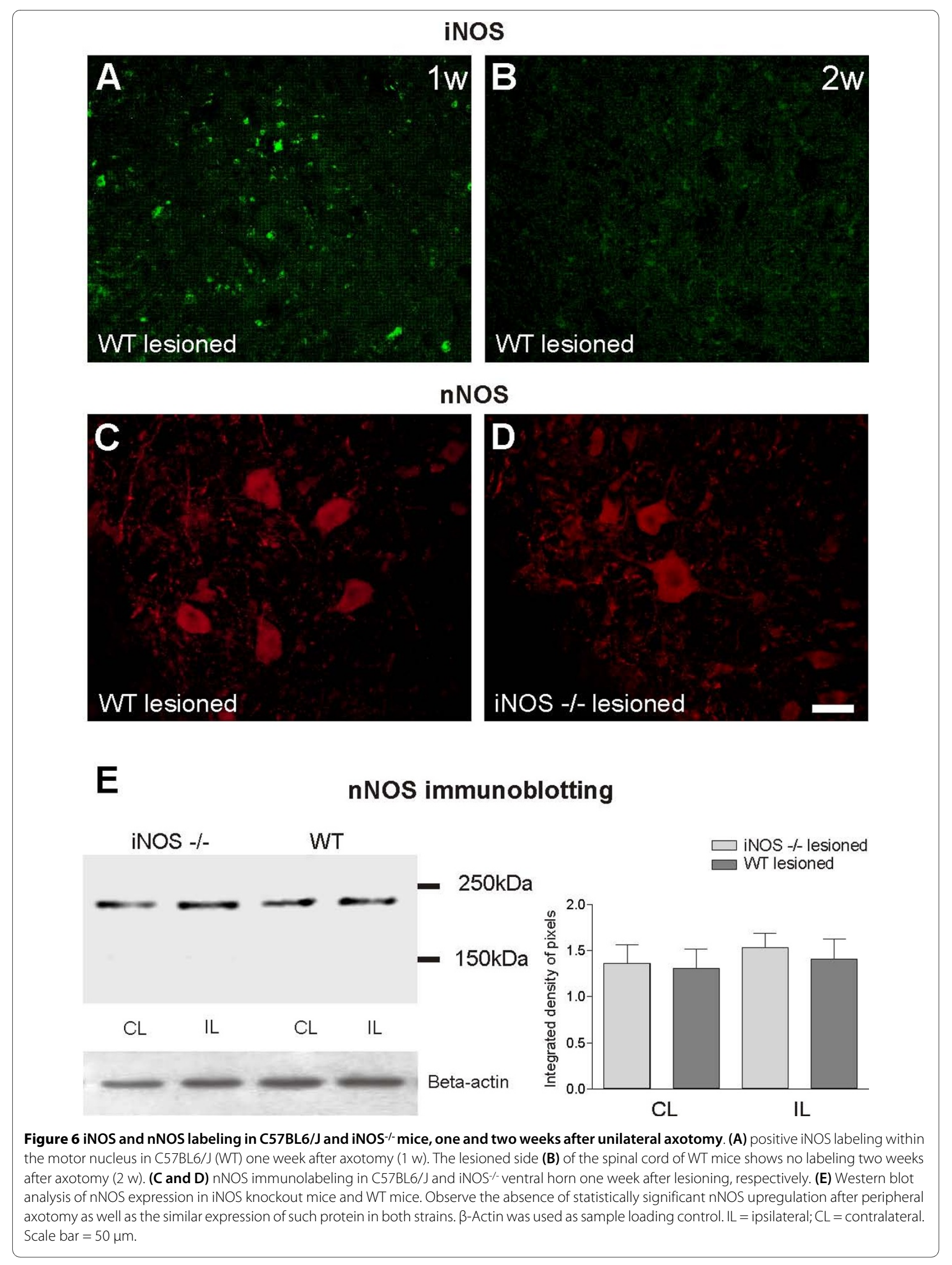




\section{Synaptic Covering}

(A)

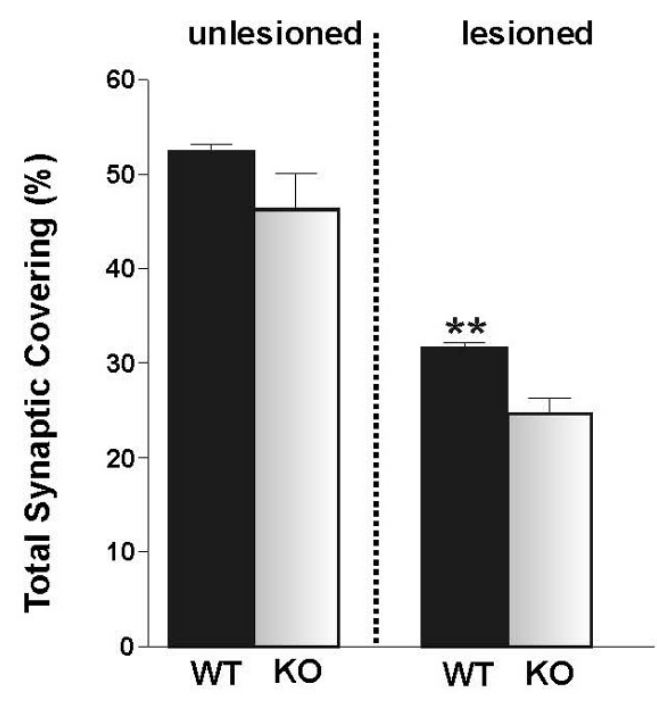

(C)

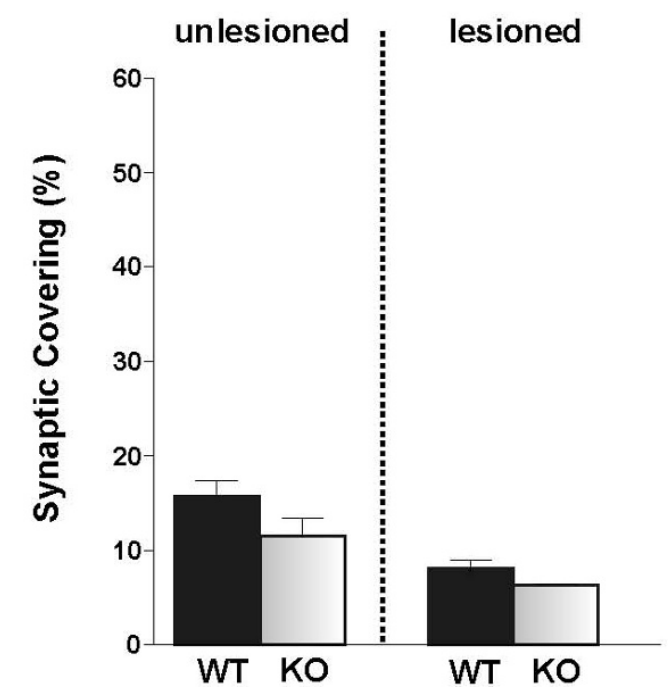

(B)

F boutons

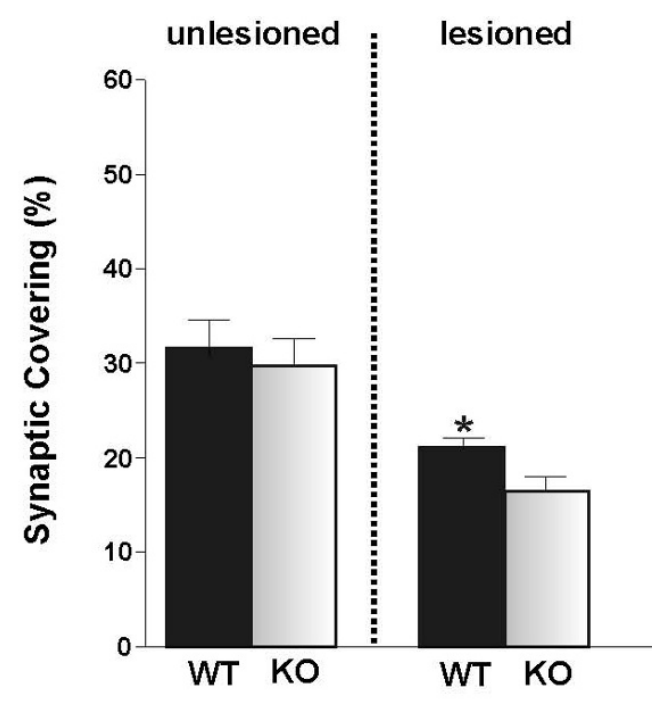

(D)

\section{C boutons}

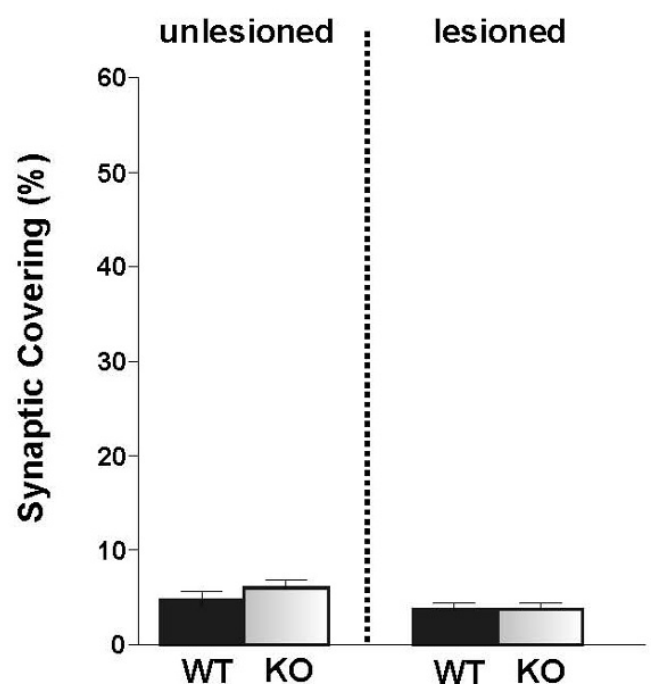

Figure 7 Synaptic covering obtained by a detailed analysis of inputs in apposition to the surface of sciatic motoneurons. (A) Percentage of absolute retraction of nerve terminals from apposition to the postsynaptic membrane in the different mice strains. One week after axotomy, a significant loss of covering can be seen in iNOS $\%$ mice as compared to C57BL6/J mice. (B - D) Percentage of synaptic covering by F-, S- and C-terminals on the unlesioned and lesioned sides. Note that after injury the iNOS-1- mice presented a greater loss of F- type terminals than the WT mice. ${ }^{*}=p<0.05$ and ${ }^{* *}=p<0.01$ (Mann-Whitney U test). 

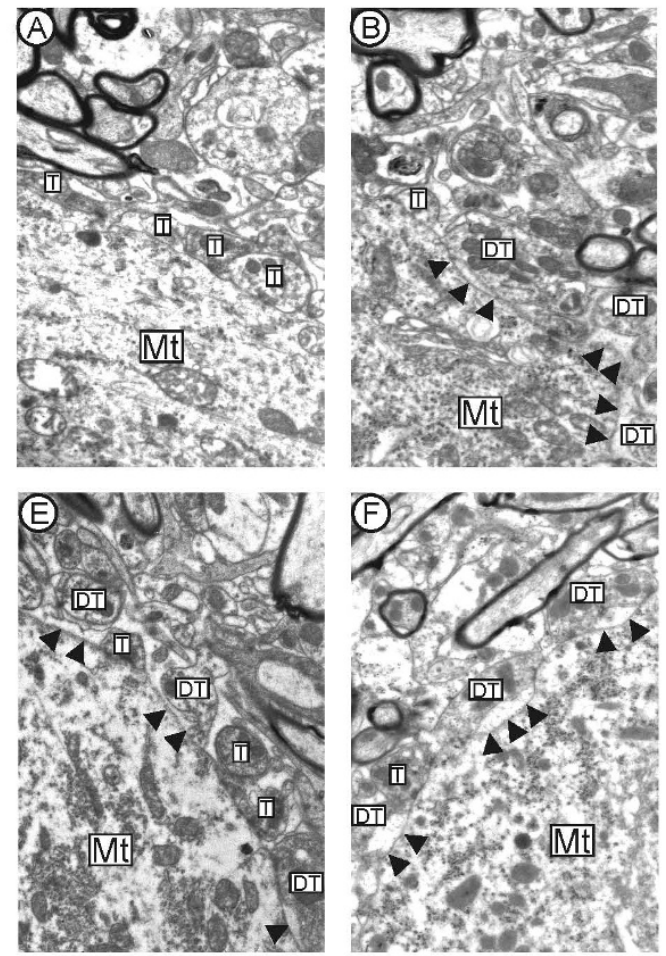

\section{Number of Terminals}

(C)

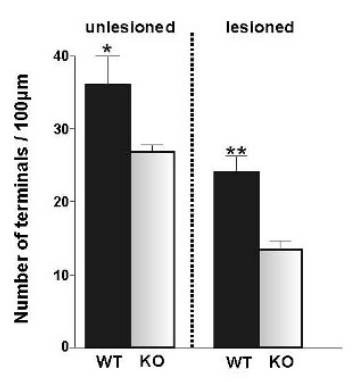

(G)

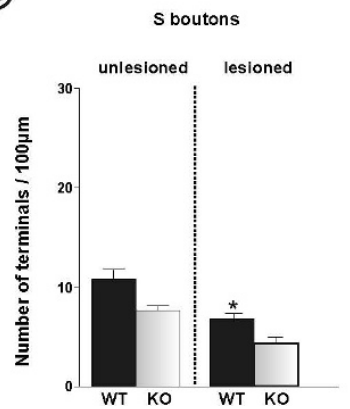

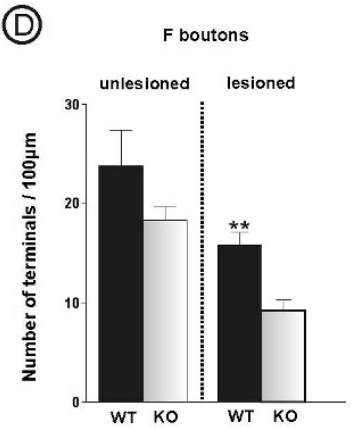

$\Theta$

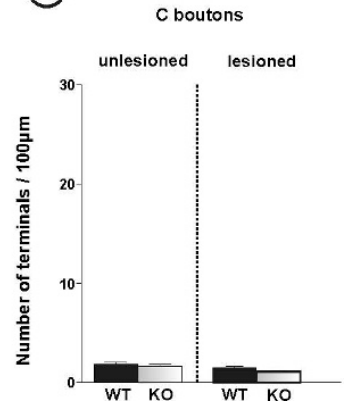

Figure 8 Quantitative ultrastructural analyses of the number of synaptic terminals apposed to the surface of motoneurons after axotomy. (A and E) Representative micrographs of the surface of unlesioned motoneurons from C57BL6/J and iNOS -1 mice strains, respectively. One week after peripheral lesion, C57BL6/J mice show a few synaptic terminals detached from the surface of lesioned motoneurons (B). Such detachment occurred to a greater degree in the ventral horn of the iNOS knockout strain (F). Observe the comparatively lower degree of synaptic covering in iNOS-1- mice as compared to C57BL6/J mice. DT = detached terminal, T = apposed terminal, Mt = motoneuron. The black arrows indicate the location of motoneuron membrane surfaces from which synaptic terminals were detached. (C) Graph of the total number of synaptic terminals per $100 \mu \mathrm{m}$ of motoneuron membrane in lesioned and unlesioned neurons. Observe that unlesioned iNOS- mice show greater synaptic elimination as compared to WT. This difference is even higher after axotomy. (F, G and H) Graphs of F-, S- and C-terminal numbers per $100 \mu \mathrm{m}$ of motoneuron membranes, respectively. A greater loss of F-type terminals can be seen one week after axotomy in iNOS-- mice. ${ }^{*}=p<0.05$ and ${ }^{* *}=p<0.01$ (Mann-Whitney Utest). Scale bar $=1 \mu \mathrm{m}$.

preserved to a smaller degree in normal mice (C57BL6/J, $6.27 \pm 1.52$; iNOS $^{-}$, $3.99 \pm 0.68, \mathrm{p}<0.05$, Figure 8G). However, in terms of $\mathrm{F}$ synaptic covering, C57BL6/J mice displayed the greatest values after transection, as shown in Figure 7B (C57BL6/J, 20.79\% $\pm 2.71 \%$; iNOS $\%$, 16.13\% $\pm 1.64 \%$, $\mathrm{p}<0.05$ ).

Figure 9A represents the normal pattern of terminal distribution along the motoneuron surface in WT mice. After axotomy, the gaps between clusters of boutons tended to increase due to selective retraction of inputs, as shown in Figure 9B. However, in the absence of iNOS, the number of gaps was decreased (Figure 9C) as a consequence of a diminished number of basal terminals characteristic of this strain, as previously shown in Figure 9A. The remaining terminals were usually close together, so that the general pattern of gap distribution was maintained. One week after axotomy, iNOS $\%$ - mice displayed a disturbed terminal distribution pattern, represented by a smaller number of gaps. In addition it was possible to find much longer gaps in the iNOS ${ }^{-1}$ mice when compared to the C57BL6/J mice (between 16 and $30 \mu \mathrm{m}$ long), indicating that the transgenic mice developed a stronger reaction to the peripheral lesion.

On the whole, these results with respect to synaptology may be interpreted to indicate that the acute response to injury is milder in C57BL6/J mice than in mice lacking inducible nitric oxide synthase, both in terms of synaptic retraction and terminal apposition surface.

\section{Discussion}

It has been reported that neurons and glial cells in the CNS can express MHC class I complex in response to different stimuli, including neurodegenerative diseases such as Huntington's disease, Parkinson's disease, autism and schizophrenia [42,43], and also following peripheral nerve axotomy $[44,24,26]$. By demonstrating that expres- 


\section{Frequency distribution}

\section{Unlesioned}

\section{A}

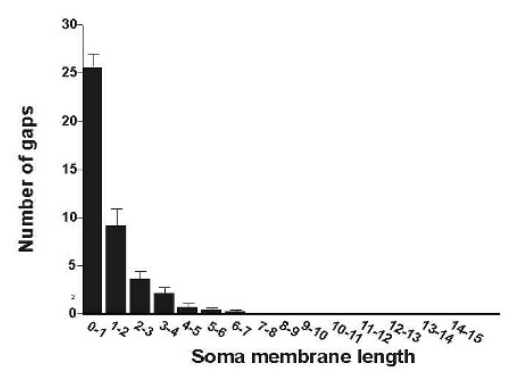

C

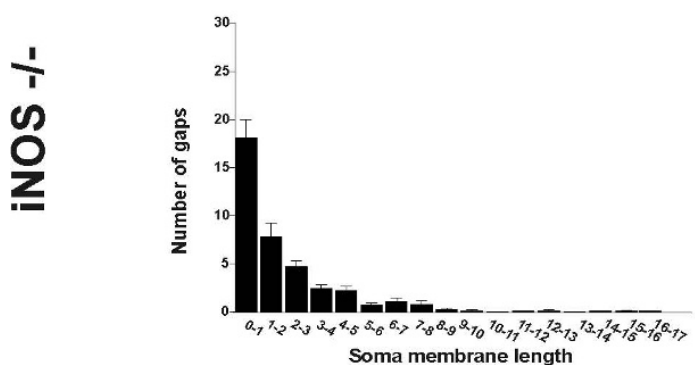

B

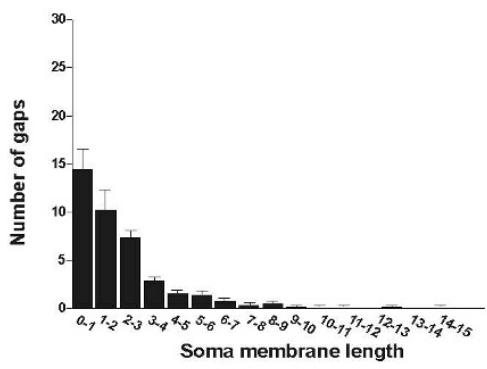

(D)

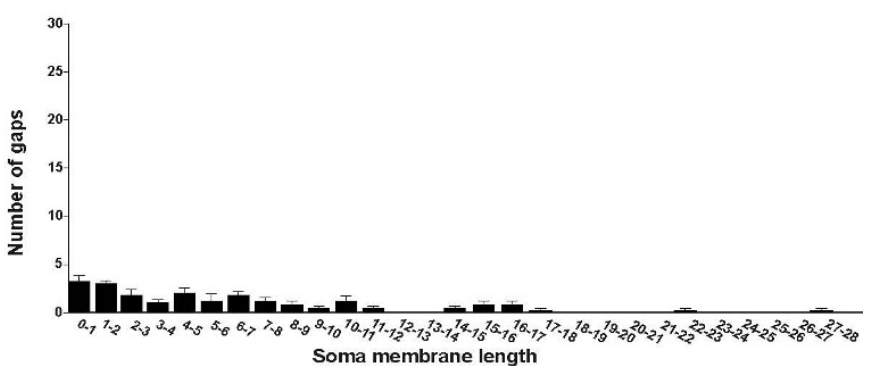

Figure 9 Graphs showing frequency distributions of gaps between terminals along the motoneuron membrane. The general gap distribution was retained in both strains one week after lesion indicating that, apart from differences regarding number and covering of terminals, synaptic elimination occurred in such a way that clusters of boutons were preserved. (A and B) Graph of the number of gaps between apposed terminals per length of membrane $(\mu \mathrm{m})$ of C57BL6/J (WT) mice on the unlesioned and lesioned sides, respectively. (C and D) Graph of the number of gaps between apposed terminals per length of membrane $(\mu \mathrm{m})$ of $\mathrm{NOSS}^{-} \%$ mice on the unlesioned and lesioned sides, respectively.

sion of this immune molecule occurs within the CNS, such findings challenged the prevailing view that the brain is "immunoprivileged" [45,46]. This process is not only restricted to MHC I molecules, but is also valid for $\mathrm{C} 1 \mathrm{q}$, the initiating protein in the classical complement cascade, which mediates CNS synapse elimination during development [47].

Lindå et al. [44] used in situ hybridization techniques to show that motoneurons express $\beta 2$-microglobulin mRNA (a co-subunit of the MHC class I complex) in response to sciatic nerve transection. In addition, a major contribution to identify putative signaling molecules in synaptic plasticity events was provided by Huh et al. [48], who demonstrated that functional expression of immune-rec- ognition MHC class I molecules is linked to the process of synaptic elimination in the developing CNS.

More recently, Oliveira et al. [23] proposed a role for classical MHC I molecules in the mechanisms of synaptic plasticity after peripheral nerve axotomy. Using $\beta 2$ microglobulin- and TAP I- (required for loading peptides onto the MHC I in the endoplasmic reticulum) knockout mice, they found that such immune molecules were involved in maintenance of inhibitory inputs after lesioning, leading to a significant detachment of glycine/ GABA-containing synapses from the cell bodies of transected motoneurons. In addition, Goddard et al. [49] showed that MHC I proteins are co-localized postsynaptically with PSD-95 in dendrites of hippocampal neuronal cells. Earlier studies also showed that neurons express the 
MHC I complex, not only after axotomy [50,51], but also during the course of viral or parasitic infections $[35,52]$ and exposure to cytokines [53]. Consequently, it is possible that the present findings indicate that the underlying mechanisms responsible for presentation of classical MHC I on the cell surface can be linked to a complex cascade of reactions in which other immune molecules and cells may be involved.

Regardless of the initial stimulus, a common response leading to NO synthesis is the upregulation of inflammatory cytokines such as interferon gamma, a potent MHC I inducer. Following peripheral lesioning, production of NO influences the expression of MHC I in the CNS microenviroment, affecting the synaptic plasticity process. The present results are consistent with this hypothesis, since $\mathrm{iNOS}^{-} /$mice displayed significantly reduced expression of MHC I one and two weeks after lesioning. This is relevant to the regenerative outcome because C57BL6/J mice, which express reduced amounts of classical MHC I compared to A/J animals, show decreased axonal growth in regenerating peripheral nerve and a delayed return of peripheral nerve function [26].

Along with the neuronal response to injury, the glial reaction also plays an important role in synaptic plasticity of the CNS after injury and, to assess this, actin-binding proteins have previously been used as effective microglial markers in immunohistochemistry [36]. Although the microglial reaction in our study did not differ between the two mice strains, MHC I protein was co-localized with the Iba-1 marker, indicating that microglia upregulate such molecules soon after axotomy. As noted previously, both microglial and astroglial cells may be implicated in synaptic elimination after neural damage $[9,34,54,55]$. In a previous study, the present authors showed that the increased astroglial reaction may be related to a greater stripping of synaptic boutons found in $\mathrm{A} / \mathrm{J}$ mice [25]. In this case, the normal activity of iNOS could lead to astrogliosis and the expression of MHC I. Conversely, a milder GFAP expression on both the unlesioned and lesioned sides of iNOS ${ }^{-1}$ mice, as compared to WT mice (in vivo as well as in vitro), could contribute to the decreased synaptic retraction observed herein. In fact, iNOS knockout mice showed a significantly decreased number of terminals per $100 \mu \mathrm{m}$ of motoneuron membrane on the contralateral (unoperated) side, reinforcing the idea that iNOS molecules could be involved in the mechanism of synapse refinement and plasticity.

The results obtained in the present study reinforce the importance of the MHC I expression by neurons and reactive glia after peripheral injury, and indicate that microglial cells respond to most glial expression of such molecules. A role for microglia in the synaptic elimination process has been suggested previously as a result of ultrastructural studies. Nonetheless, secondarily activated astrocytes may contribute to maintenance of the synaptic elimination process in the acute phase after injury, since their cytoplasmic processes interpose between retracted pre-synaptic terminals and the motoneuron cell membrane.

NO production in the CNS is related to an increasingly diverse variety of responses that range from intercellular signaling to the necrotic death of cells and the response to invading pathogens. On the other hand, due to the absence of selective NOS inhibitors, it has been difficult to assign specific roles to the different isoforms. NOS-2, or iNOS, is an enzyme capable of producing a continuous flux of $\mathrm{NO}$ in the presence of adequate substrate and cofactors. It is expressed in most cells after induction by immunologic and inflammatory stimuli [56]. The present study demonstrates that sciatic nerve transection induces different levels of $\mathrm{H} 2-\mathrm{D}^{\mathrm{b}}$ and $-\mathrm{K}^{\mathrm{b}}$ expression in C57BL6/J and iNOS $^{-1-}$ mice. The iNOS isoform is expressed by astrocytes, macrophages and microglia, following an immunological or inflammatory stimulation $[29,31,57]$.

\section{Conclusion}

In conclusion, the present study shows that knockout mice for the inducible form of NOS display decreased expression of MHC I after lesioning and greater synaptic elimination after peripheral axotomy. Such changes correlate with increased microglial activity without expression of MHC I, coupled with reduced astroglial reaction. These observations are in line with the greater synaptic loss observed in mutant mice that are unable to express MHC I [23]. Further studies aimed at increasing local iNOS activity may investigate upregulation of MHC I molecules by glial cells, which may increase the possibility of a better regenerative outcome after injury.

\section{Competing interests}

The authors declare that they have no competing interests.

\section{Authors' contributions}

AE designed and performed the experiments, analyzed the data, prepared the figures and wrote the manuscript. GFS contributed to the acquisition and analysis of the data. RGZ performed the western blotting analyses. ALRO conceived and designed the study, analyzed the data and wrote the manuscript. All authors read and approved the final manuscript.

\section{Acknowledgements}

This work was supported by Fapesp (2010/07471-0). Amanda Emirandetti received Ph.D. scholarships from CAPES and CNPq. Gustavo F. Simões received a Ph.D. scholarship from CAPES. A.L.R.O. received a fellowship from CNPq, proc. 304834/2006-8.

\section{Author Details}

Department of Anatomy, Institute of Biology, University of Campinas (UNICAMP), CP 6109, CEP 13083-970, Campinas, SP, Brazil

Received: 4 September 2009 Accepted: 24 May 2010

Published: 24 May 2010 


\section{References}

1. Lamas S, Marsden PA, Li GK, Tempst P, Michel T: Endothelial nitric oxide synthase: molecular cloning and characterization of a distinct constitutive enzyme isoform. Proc Natl Acad Sci USA 1992, 89:6348-6352.

2. Elfering SL, Sarkela TM, Giulivi C: Biochemistry of mitochondrial nitric oxide synthase. J Biol Chem 2002, 277:38079-38086.

3. Navarro A, Boveris A: Mitochondrial nitric oxide synthase, mithocondrial brain dysfunction in aging, and mithocondrial-targeted antioxidants. Adv Drug Deliv Rev 2008, 60:1534-1544.

4. Iadecola C: Regulation of the cerebral microcirculation during neuronal activity: is nitric oxide the missing link? Trends Neurosci 1993, 16:206-214

5. Toda N, Ayajiki K, Okamura T: Cerebral blood flow regulation by nitric oxide: recent advances. Pharmacol Rev Mar 2009, 61:62-97.

6. Suematsu M, Wakabayashi Y, Ishimura Y: Gaseous monoxides: a new class of microvascular regulator in the liver. Cardiovasc Res 1996 32:679-86.

7. Zochodne DW, Levy D, Zwiers H, Sus H, Rubin I, Cheng C, Lauriziten M: Evidence for nitric oxide and nitric oxide synthase activity in proximal stumps of transected peripheral nerves. Neurosci 1999, 91:1515-1527.

8. Cristino L, Pica A, Della Corte F, Bentivoglio M: Co-induction of nitric oxide synthase, $\mathrm{BCL}-2$ and growth-associated protein- 43 in spinal motoneurons during axon regeneration in the lizard tail. Neuros $\mathrm{C} i$ 2000, 101:451-458.

9. Levy D, Kubes P, Zochodne DW: Delayed peripheral nerve degeneration, regeneration, and pain in mice lacking inducible nitric oxide synthase. J Neuropathol Exp Neurol 2001, 60:411-421.

10. Dawson VL, Dawson TM: Nitric oxide neurotoxicity. J Chem Neuroanat 1996, 10:179-190.

11. Ernst AF, Gallo G, Letourneau PC, McLoon SC: Stabilization of growing retinal axons by the combined signaling of nitric oxide and brainderived neurotrophic factor. J Neurosci 2000, 20:1458-1469.

12. Schuman EM, Madison DV: Nitric oxide and synaptic function. Annu Rev Neurosci 1994, 17:153-183.

13. Hayden MA, Lange PA, Nakayama DK: Nitric oxide and cyclic guanosine monophosphatase stimulate apoptosis via activation of the fas-fasL pathway. J Surg Res 2001, 101:183-189.

14. Chung HT, Pae HO, Choi BM, Billar TR, Kim YM: Breakthroughs and views of nitric oxide as a bioregulator of apoptosis. Biochem Biophys Res Commun 2001, 282:1075-1079.

15. Keilhoff G, Hisham F, Wolf G: Neuronal nitric oxide synthase is the dominant nitric oxide supplier for the survival of dorsal root ganglia after peripheral nerve axotomy. J Chem Neuroanat 2002, 24:181-187.

16. Thippeswamy T, McKay JS, Morris R: Bax and caspases are inhibited by endogenous nitric oxide in dorsal root ganglion neurons in vitro. Eur J Neurosci 2001, 14:1229-1236.

17. Koeberle PD, Ball AK: Nitric oxide synthase inhibition delays axonal degeneration and promotes the survival of axotomized retinal ganglion cells. Exp Neurol 1999, 158:366-381.

18. Fiallos-Estrada EC, Kummer W, Mayer B, Bravo R, Zimmermman M, Herdegen T: Long-lasting increase of nitric oxide synthase immunoreactivity, NADPH-diaphorase reaction and c-JUN coexpression in rat dorsal root ganglion neurons following sciatic nerve transection. Neurosci Lett 1993, 150:169-173.

19. Zhang X, Verge V, Wiesenfeld-Hallin Z, Ju G, Bredt D, Synder SH, Hökfelt T: Nitric oxide synthase-like immunoreactivity in lumbar dorsal root ganglia and spinal cord of rat and monkey and effect of peripheral axotomy. J Comp Neurol 1993, 335:563-575.

20. Gonzáles-Hernández T, Rustioni A: Expression of three forms of nitric oxide synthase in peripheral nerve regeneration. J Neurosci Res 1999, 55:198-207

21. Verge $V M, X u Z, X u X J$, Wiesenfeld $H Z$, Hokfelt T: Marked increase in nitric oxide synthase mRNA in rat dorsal root ganglia after peripheral axotomy: in situ hybridization and functional studies. Proc Natl Acad Sci USA 1992, 89:11617-11621.

22. Edström E, Kullberg S, Ming Y, Zheng H, Ulfhake B: MHC class I, $\beta_{2^{-}}$ microglobulin, and INF- $\gamma$ receptor are upregulated in aged motoneurons. J Neurosci Res 2004, 78:892-900.

23. Oliveira AL, Thams S, Lidman O, Piehl F, Hökfelt T, Kärre K, Lindå H, Cullheim S: A role for MHC class I molecules in synaptic plasticity and regeneration of neurons after axotomy. Proc Natl Acad Sci USA 2004, 101:17843-17848.
24. Zanon RG, Oliveira AL: $\mathrm{MHCl}$ upregulation influences astroglial reaction and synaptic plasticity in the spinal cord after sciatic nerve transection. Exp Neurol 2006, 200:521-531.

25. Emirandetti A, Zanon RG, Sahba M Jr, De Oliveira AL: Astrocyte reactivity influences the number of presynaptic terminals apposed to spinal motoneurons after axotomy. Brain Res 2006, 1095:35-42.

26. Sabha M Jr, Emirandetti A, Cullheim S, Oliveira ALR: MHC I expression and synaptic plasticity in different mice strains after axotomy. Synapse 2008, 62:137-148

27. Lu L, Richardson PM, Gervais F, Skamene E: A deficiency of axonal regeneration in C57BL/6J mice. Brain Res 1990, 510:144-146.

28. Lu X, Skamene E, Richardson PM: Studies of axonal regeneration in C57BL/6J and A/J mice. Brain Res 1994, 652:174-176.

29. Lee SC, Dickson DW, Liu W, Brosnan CF: Induction of nitric oxide synthase activity in human astrocytes by interleukin-1 beta and interferon-gamma. J Neuroimmunol 1993, 46:19-24.

30. Kamijo R, Harada H, Matsuyama T, Bosland M, Gerecinato J, Shapiro D, Le J, Koh SI, Kimura T, Green SJ: Requirement for transcription factor IRF-1 in NO synthase induction in macrophages. Science 1994, 263:1612-1615.

31. Saha RN, Pahan K: Signals for the induction of nitric oxide synthase in astrocytes. Neurochem Intern 2006, 49:154-163.

32. Mohammed NA, Abd El-Aleem S, Appleton I, Maklouf MM, Said M McMahon RF: Expression of nitric oxide synthase isoforms in human liver cirrhosis. J Pathol 2003, 200:647-655.

33. Bucher M, Ittner KP, Zimmermann M, Wolf K, Hobbhahn J, Kurtz A: Nitric oxide synthase isoform III gene expression in rat liver is up-regulated by lipopolysaccharide and lipoteichoic acid. FEBS Lett 1997, 412:511-514.

34. Romero-Sandoval A, Chai N, Nutile-McMenemy N, DeLeo JA: A comparison of spinal 1 and GFAP expression in rodent models of acute and chronic pain. Brain Res 2008, 1219:116-126.

35. Inoue K, Tsuda M: Microglia and neuropathic pain. Glia 2009, 57:1469-1479

36. Ahmed Z, Shaw G, Sharma VP, Yang C, McGowan E, Dickson DW: Actinbinding proteins coronin- $1 \mathrm{a}$ and -1 are effective microglial markers for immunohistocheistry. J Histochem Cytochem 2007, 55:687-700.

37. Conradi S: Ultrastructure and distribution of neuronal and glial elements on the motoneuron surface in the lumbossacral spinal cord of the adult cat. Acta Physiol Scand Supp/ 1969, 332:5-48.

38. Arvidsson U, Riedl M, Elde R, Meister B: Vesicular acetylcholine transporter (VAChT) protein: a novel and unique marker for cholinergic neurons in the central and peripheral nervous systems. J Comp Neurol 1997, 378:454-467.

39. Connaughton $\mathrm{m}$, Priestley JV, Sofroniew MV, Eckenstein F, Cuello AC Inputs to neurons in the hypoglossal nucleus of the rat: light and electron microscopic immunocytochemistry for choline acetyltransferase, substance $P$ and enkephalins using monoclona antibodies. Neurosci 1986, 17:205-224.

40. Ornung G, Shupliakov O, Ottersen OP, Storm-Mathisen J, Cullheim S: Immunohistochemical evidence for coexistence of glycine and GABA in nerve terminals on cat spinal motoneurones: an ultrastructural study. Neuroreport 1994, 5:889-892.

41. Shupliakov O, Ornung G, Brodin L, Ulfhake B, Ottersen OP, StormMathisen J, Cullheim S: immunocytochemical localization of amino acid neurotransmitter candidates in the ventral horn of the cat spinal cord: a light microscopic study. Exp Brain Res 1993, 96:404-18.

42. Tiwari JL, Terasaki PI: HLA and disease associations Spring-Verlag New York; 1985.

43. Torres AR, Maciulis A, Odell D: The association of MHC genes with autism. Front Biosci 2001, 6:D936-943.

44. Lindå $\mathrm{H}$, Hammarberg $\mathrm{H}$, Cullheim S, Levinovitz A, Khademi M, Olsson T: Expression of $\mathrm{MHC}$ class I and $\beta 2$-microglobulin in rat spinal motoneurons; regulatory influences by INF-gamma and axotomy. Exp Neurol 1998, 150:282-295.

45. Hickey WF: Basic principles of immunological surveillance of the normal central nervous system. Glia 2001, 36:118-124

46. Becher B, Bechmann I, Greter M: Antigen presentation in autoimmunity and CNS inflammation: how T lymphocytes recognize the brain. $J \mathrm{Mol}$ Med 2006, 84:532-543.

47. Stevens B, Allen NJ, Vazquez LE, Howell GR, Christopherson KS, Nouri N, Micheva KD, Mehalow AK, Huberman AD, Stafford B, Sher A, Litke AM, 
Lambris JD, Smith SJ, John SW, Barres BA: The classical complement cascade mediates CNS synapse elimination. Cell 2007, 131:1164-1178,

48. Huh GS, Boulanger LM, Du H, Riquelme PA, Brotz TM, Shatz CJ: Functional requirement for class I MHC in CNS development and plasticity. Science 2000, 290:2155-2159.

49. Goddard CA, Butts DA, Shatz CJ: Regulation of CNS synapses by neuronal MHC class I. Proc Natl Acad Sci USA 2007, 104:6828-6833.

50. Olsson T, Kristensson K, Ljungdahl A, Maehlen J, Holmdahl R, Klareskog L: Gamma-interferon-like immunoreactivity in axotomized rat motor neurons. J Neurosci 1988, 11:3870-3875.

51. Maehlen J, Schröder HD, Klareskog L, Olsson T, Kistensson K: Axotomy induces $\mathrm{MHC}$ class I antigen expression on rat nerve cells. Neurosci Lett 1988, 92:8-13.

52. Redwine JM, Buchmeier MJ, Evans CF: In vivo expression of major histocompatibility complex molecules on oligodendrocytes and neurons during viral infection. Am J Pathol 2001, 159:1219-1224.

53. Foster JA, Quan N, Stern EL, Kristensson K, Herkenham M: Induced neuronal expresion of class I major histocompatibility complex mRNA in acute and chronic inflammation models. J Neuroimmunol 2002, 131:83-91.

54. Newmann H, Cavalie A, Jenne DE, Wekerle H: Induction of MHC class I genes in neurons. Science 1995, 269:549-552.

55. Aldskogius H, Liu L, Svensson M: Glial responses to synaptic damage and plasticity. J Neurosci Res 1999, 58:33-41.

56. Nathan C: Inducible nitric oxide synthase: what difference does it make? J Clin Invest 1997, 100:2417-2423.

57. Kamijo R, Harada H, Matsuyama T, Bosland M, Gerecitano J, Shapiro D, Le J, Koh SI, Kimura T, Green SJ: Requirement for transcription factor IRF-1 in NO synthase induction in macrophages. Science 1994, 263:1612-1615.

doi: 10.1186/1742-2094-7-31

Cite this article as: Emirandetti et al., Spinal motoneuron synaptic plasticity after axotomy in the absence of inducible nitric oxide synthase Journal of Neuroinflammation 2010, 7:31

Submit your next manuscript to BioMed Central and take full advantage of:

- Convenient online submission

- Thorough peer review

- No space constraints or color figure charges

- Immediate publication on acceptance

- Inclusion in PubMed, CAS, Scopus and Google Scholar

- Research which is freely available for redistribution

Submit your manuscript at www.biomedcentral.com/submit
C) Biomed Central 